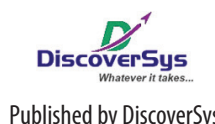

Published by DiscoverSys

\section{Association between nursing care performance with perception of financial rewards, career development and supervision}

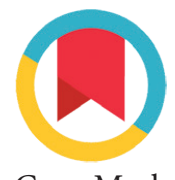

CrossMark

Ayu Ratih Cempakasari,,$^{*}$ Ni Made Sri Nopiyani, ${ }^{2}$ Dyah Pradnyaparamitha Duarsa ${ }^{2}$

\title{
ABSTRACT
}

Background and purpose: The performance of nurses in providing care to patients is an important component for patient satisfaction and healing. Nurse's performance is determined by many factors. This study aims to determine the association between nurse performance in providing nursing care with education, nurse perceptions of financial rewards, career development opportunities, and supervision of the ward head.

Methods: A cross-sectional survey was conducted on all nurses (164 people) at inpatient wards of Tabanan General Hospital. Data collection was carried out using a self-administered questionnaire in April 2018. Bivariate analysis was performed using chi-square test, and multivariate analysis was conducted using multiple logistic regression to determine the adjusted odds ratios.
Results: The results showed that the mean score of nursing care performance was 70.17 from a maximum score of 80 . All independent variables were found to be associated with nurse performance, namely perceptions of career development opportunities (AOR=1.6; $95 \% \mathrm{Cl}$ : 1.03-1.3; $p=0.01)$, financial rewards $(A O R=1.1 ; 95 \% \mathrm{Cl}: 1.01-1.2$; $p=0.03)$ and supervision of the ward chief $(A O R=1.1 ; 95 \% \mathrm{Cl}: 1.01-1.2$; $p=0.02)$.

Conclusion: Nurses' perceptions of financial rewards, career development opportunities, and supervision of the ward chief are associated with nursing care performance. Provision of rewards, career development and supervision need to be considered in the efforts to improve nurse performance.
'Public Health Postgraduate Program, Faculty of Medicine, Udayana University, ${ }^{2}$ Department of Public Health and Preventive Medicine, Faculty of Medicine, Udayana University
*Correspondence to: Ayu Ratih Cempakasari, Public Health Postgraduate Program, Faculty of Medicine, Udayana University, ayuratihcempaka@gmail.com

Keywords: performance of nursing care, financial rewards, career development, supervision Cite This Article: Cempakasari, A.R., Nopiyani, N.M.S., Duarsa, D. P. 2019. Association between nursing care performance with perception of financial rewards, career development and supervision. Public Health and Preventive Medicine Archive 7(1): 3-7. D01:10.15562/phpma.v7i1.184

\section{INTRODUCTION}

The quality of health services remains a global challenge in both developed and developing countries. ${ }^{1}$ The better public awareness of their health, the higher the demands of the community for quality of health services including hospital services. ${ }^{2}$ Nurses are the main health human resource in hospitals that determine the quality of service due to their intensive interaction with patients. ${ }^{3}$ However, the provision of nursing care is often perceived inadequate by patients, families, and other health workers. ${ }^{4}$ Assessment of nurse performance in providing care is an important feedback for improving the quality of care. ${ }^{5}$ The results of studies on factors related to nurse performance have been widely published, but those that specifically examine nurses performance in nursing care are still limited in Indonesia. ${ }^{6-10}$

This study aims to determine the performance of nurses in providing nursing care as well as its association with education levels, financial rewards, career development opportunities and supervision of the ward chief.

\section{METHODS}

A cross-sectional survey was conducted at Tabanan District Hospital. The hospital is a type B public teaching hospital for medical doctors, nurses and other health professionals. The hospital has 164 nurses in charged for inpatient wards. The educational backgrounds of the nurses at Tabanan General Hospital consisted of high school, diploma and bachelor. Nurses with diploma and bachelor backgrounds have similar responsibilities in terms of providing care for the patients, while those with high school background are responsible to assist nurses with higher level of education.

Respondents of the study were all nurses at the inpatient wards. The other eligibility criteria are those who had worked at least 6 months, were willing to be respondents, were not continuing their education and were not holding structural position. Data collection was carried out using a self-administered questionnaire in April 2018. The questionnaire consisted of five parts, namely socio-demographic characteristics, nurses' perceptions of financial rewards, career development opportunities, supervision of the ward chief and nursing care performance. Perceptions of financial rewards and career development opportunities were measured through eight statements. The perception of supervision of the ward chief consisted of 10 statements. Meanwhile, the nursing care performance was explored through 20 statements. Each statement had four alternative 
responses. For financial rewards and career development opportunities there were four possible responses namely "strongly disagree" given a score of 1 , "disagree" given a score of 2 , "agree" given a score of 3 , and "strongly agree" given a score of 4 . Whereas in the nurse performance and supervision of the ward chief, responses "never" given a score of 1 , "sometimes" given a score of 2 , "often" given a score of 3 and "always" given a score of 4 .

The scores of each statement are summed up to obtain the total score for each variable, namely the total score of perceptions of financial rewards, career development opportunities, supervision of the ward chief and nursing care performance. Furthermore, the total score of each variable is categorized into "good" and "poor" with a cut-off point of mean from the total score.

Data were analyzed using STATA SE 12.1. Bivariate analysis was performed with chi-square test and multivariate analysis with multiple logistic regression. Variables that have a $\mathrm{p}$ value of $<0.25$ in bivariate analysis are included in the model in multivariate analysis. In multivariate analysis, all of the independent variables, except the level of education are treated as interval scale. This study has been approved by the Ethics Committee of the Faculty of Medicine, Udayana University/Sanglah General Hospital Denpasar on April 3, 2018.

\section{Table 1 Socio-demographic characteristics}

\begin{tabular}{lcc}
\hline Characteristics & $\mathbf{n}$ & $\%$ \\
\hline Age (years) & & \\
$\quad \leq 32$ & 84 & 51.2 \\
$\quad>32$ & 80 & 48.8 \\
Gender & 22 & \\
$\quad$ Male & 142 & 13.4 \\
$\quad$ Female & & 86.6 \\
Length of working (years) & 90 & \\
$\quad \leq 10$ & 74 & 54.9 \\
$\quad>10$ & & 45.1 \\
Marital status & 145 & \\
$\quad$ Married & 19 & 88.4 \\
$\quad$ Unmarried & & 11.6 \\
Employment & 70 & \\
$\quad$ Civil servant & 94 & 42.7 \\
$\quad$ Non-permanent employee & & 57.3 \\
Education & 7 & \\
High school & 100 & 61.3 \\
Diploma & 57 & 34.8 \\
Bachelor & 164 & 100.0 \\
Total & & \\
\hline
\end{tabular}

\section{RESULTS}

The socio-demographic characteristics of respondents are presented in Table 1 . The age of respondents ranged from 23 to 56 years, with a median age of 32 years. The majority of respondents were female and married. As many as $61 \%$ of respondents were diploma in nursing and more than $50 \%$ of respondents were non-permanent employees. Respondents' length of working were varied from 6 months to 35 years, with a median of 10 years.

Table 2 presents the frequency distribution and descriptive statistics of respondents' perceptions of financial rewards, career development opportunities, supervision of the ward chief and nurse performance in providing nursing care. The proportion of nurses who perceived financial rewards and supervision of the ward chief as 'good' and 'poor' were almost equal. Meanwhile, in terms of career development opportunities the majority of respondents provided poor ratings.

The mean score of nurses' perceptions of financial rewards is $23.26(\mathrm{SD}=4.79)$ from a possible maximum score of 32 . The lowest score in the financial reward component is the suitability between the salary received and the workload. The mean score of nurses' perceptions of career development opportunities is $24.01(\mathrm{SD}=3.56)$ from a possible maximum score of 32 . The lowest score of career development opportunities is the provision of promotion to employees who participate well in trainings. The perception of the supervision had a mean score of 28.75 ( $\mathrm{SD}=5.61)$ from a possible maximum score of 40 . The lowest score was found in terms of encouragement for group discussion on nursing care by the ward chief. The mean score of nurses' perceptions of their performance in carrying out nursing care is $70.17(\mathrm{SD}=9.09)$ from a possible maximum score of 80 . The performance's aspect with the lowest score is in terms of collecting data about bio-psycho-social-spiritual of patients.

Table 3 presents the results of bivariate analysis between education, perceptions of financial rewards, career development opportunities, supervision of the ward chief, age, length of work, gender, marital status, and employment with nursing care performance. Variables that have $p$ value $<0.25$, namely the level of education, perceptions of financial rewards, career development opportunities and supervision of the ward chief, were included in multivariate analysis with multiple logistic regression.

Table 4 shows that the variables related to nurse performance in providing nursing care are nurses perceptions of financial rewards (AOR=1.094; 95\%CI: 1.010-1.186; $\mathrm{p}=0.03$ ), career development opportunities $\quad(\mathrm{AOR}=1.151 ; 95 \% \mathrm{CI}$ : 
Table 2 Perceptions of service rewards, career development opportunities, supervision of the ward chief and nurse performance

\begin{tabular}{lcccccc}
\hline Perceptions & No item & $\mathbf{n}(\%)$ & Mean & SD & Min & Max \\
\hline Service rewards & 8 & & 23.26 & 4.79 & 11 & 32 \\
$\quad$ Good & & $80(48.8)$ & & & & \\
$\quad$ Poor & & $84(51.2)$ & & & & \\
$\quad$ Career development opportunities & 8 & & 24.01 & 3.56 & 12 & 32 \\
$\quad$ Good & & $43(26.2)$ & & & & \\
$\quad$ Poor & 10 & $121(73.8)$ & & & & \\
$\quad$ Supervision of the ward chief & 10 & & 28.75 & 5.61 & 13 & 40 \\
$\quad$ Good & & $97(59.1)$ & & & & \\
$\quad$ Poor & $67(40.9)$ & & & & \\
$\quad$ Nurse performance & 20 & & 70.17 & 9.09 & 44 & \\
$\quad$ Good & & $89(54.3)$ & & & & \\
$\quad$ Poor & & $75(45.7)$ & & & & \\
$\quad$ Total & & $164(100.0)$ & & & & \\
\hline
\end{tabular}

Table 3 Association between financial rewards, career development opportunities, supervision of the ward chief and nursing care performance

\begin{tabular}{|c|c|c|c|}
\hline \multirow[b]{2}{*}{ Variable } & \multicolumn{2}{|c|}{ Performance } & \multirow[b]{2}{*}{ p value } \\
\hline & $\begin{array}{l}\text { Good } \\
\text { n (\%) }\end{array}$ & $\begin{array}{l}\text { Poor } \\
\text { n (\%) }\end{array}$ & \\
\hline \multicolumn{4}{|l|}{ Education } \\
\hline School of Nursing & $3(42.9)$ & $4(57.1)$ & 0.23 \\
\hline Diploma of Nursing & $50(50.0)$ & $50(50.0)$ & \\
\hline Bachelor of Nursing & $36(63.2)$ & $21(36.8)$ & \\
\hline \multicolumn{4}{|l|}{ Financial rewards } \\
\hline Good & $48(60.0)$ & $32(40.0)$ & 0.15 \\
\hline Poor & $41(48.8)$ & $43(51.2)$ & \\
\hline \multicolumn{4}{|c|}{ Career development opportunities } \\
\hline Good & $35(81.4)$ & $8(18.6)$ & $<0.01$ \\
\hline Poor & $54(44.6)$ & $67(55.4)$ & \\
\hline \multicolumn{4}{|c|}{ Supervision of the ward chief } \\
\hline Good & $58(59.8)$ & $39(40.2)$ & 0.09 \\
\hline Poor & $31(46.3)$ & $36(53.7)$ & \\
\hline \multicolumn{4}{|l|}{ Age (years) } \\
\hline$\leq 32$ & $45(53.6)$ & $39(46.4)$ & 0.85 \\
\hline$>32$ & $44(55.0)$ & $36(45.0)$ & \\
\hline \multicolumn{4}{|c|}{ Length of working (years) } \\
\hline$\leq 10$ & $51(56.7)$ & $39(43.3)$ & 0.50 \\
\hline$>10$ & $38(51.4)$ & $36(48.6)$ & \\
\hline \multicolumn{4}{|l|}{ Gender } \\
\hline Male & $12(54.5)$ & $10(45.5)$ & 0.98 \\
\hline Female & $77(54.2)$ & $65(45.8)$ & \\
\hline \multicolumn{4}{|l|}{ Marital status } \\
\hline Married & $77(53.1)$ & $68(46.9)$ & 0.41 \\
\hline Unmarried & $12(63.2)$ & $7(36.8)$ & \\
\hline
\end{tabular}


Table 3 Continue

\begin{tabular}{lccc}
\hline & \multicolumn{2}{c}{ Performance } & \\
\cline { 2 - 3 } Variable & $\begin{array}{l}\text { Good } \\
\mathbf{n}(\%)\end{array}$ & $\begin{array}{l}\text { Poor } \\
\mathbf{n}(\%)\end{array}$ & p value \\
\hline Employment & & & 0.75 \\
$\quad$ Civil servant & $39(55.7)$ & $31(44.3)$ & \\
$\quad$ Non-permanent employee & $50(53.2)$ & $44(46.8)$ & \\
\hline
\end{tabular}

Table 4 Adjusted OR of education levels, perception of financial rewards, career development opportunities, and supervision by the ward chief

\begin{tabular}{lcccc}
\hline & & \multicolumn{2}{c}{$\mathbf{9 5 \%} \mathbf{C l}$} \\
\cline { 5 - 5 } Variable & Adjusted OR & Lower & Upper & p value \\
\hline Education & Ref & & & \\
$\quad$ High school of nursing & 3.199 & 0.465 & 22.02 & 0.24 \\
$\quad$ Diploma of nursing & 6.807 & 0.915 & 50.67 & 0.06 \\
$\quad$ Bachelor of nursing & 1.094 & 1.010 & 1.186 & 0.03 \\
Financial rewards & 1.151 & 1.033 & 1.283 & 0.01 \\
Career development opportunities & 1.085 & 1.012 & 1.164 & 0.02 \\
Supervision by the ward-chief & & & & \\
\hline
\end{tabular}

1.033-1.283; $\mathrm{p}=0.01)$ and supervision of the ward chief $(\mathrm{AOR}=1.094 ; 95 \% \mathrm{CI}: 1.010-1.186 ; \mathrm{p}=0.03)$.

\section{DISCUSSION}

In this study, the mean score of nurses' performance in providing nursing care was 70.17 and as many as $54 \%$ of nurses had relatively good performance. In the study at Datoe Binangkang Hospital in Bolaang Mongondow Regency and in Sragen General Hospital, it was found that the proportion of nurses who performed well was $60 \%$, slightly higher than the proportion found in our study. ${ }^{8,11}$ This difference can be caused by differences in instruments, methods, and standards used at the time of the study. In this study, the performance in data collection of patient bio-psychosocial-spiritual received the lowest scores. This is possibly due to the complexity and comprehensiveness of bio-psycho-social-spiritual data that requires extra time and lead to additional workload of nurses. ${ }^{12}$

The results of this study indicate that an increase in nurses' perceptions of financial rewards is significantly associated with an increase in nursing care performance. The findings of this study are supported by studies in Palu, Manado, and Palembang Hospitals which also shows that financial rewards are significantly associated to the performance of nurses in hospitals. ${ }^{7,9,13}$ However, the opposite results were obtained from the study conducted at Sragen General Hospital which showed that the reward system was not associated with nurse performance. ${ }^{11}$ This difference could be due to the fact that the study subjects were made up entirely of civil servants while the subjects in our study consisted of civil servant and non-permanent nurses in almost the same proportion.

The results of multivariate analysis in this study also showed that an increase in perceptions of career development opportunities was related to the improvement of nursing care performance. These findings are in line with studies conducted at the A.W.Sjahranie General Hospital and Dr. Mintohardjo Military Hospital which showed that career development is associated with the performance of nurses. ${ }^{14,15}$ Career development opportunities are a form of self-development to improve knowledge and skills, which can be taken through formal and informal education. Career development opportunities for nurses can increase job satisfaction, increase retention, and motivate nurses to provide quality health services. ${ }^{16,17}$

Nurses' perceptions of supervision of the ward chief in this study were significantly associated with nursing care performance. The results of this study are supported by studies at $\mathrm{H}$. Hanafie Muara Bungu Hospital and Bethesda Gmim Tomohon Hospital which shows that there is a significant relationship between supervision and the performance of nurses in hospitals. ${ }^{18,19}$ Close supervision can increase enthusiasm and nurse motivation. ${ }^{18,19}$ Moreover, supervision is a means to improve work professionalism, knowledge and skills and can reduce work related stress. ${ }^{20}$

The limitation of this study is that nursing care performance measurement is carried out through 
self-assessment with a self-administered questionnaire, not by observation, so the results may not be objective.

\section{CONCLUSION}

Nurses perceptions of financial rewards, career development opportunities, and supervision of ward chief are associated to nurses performance in providing nursing care. These three factors need to be considered in the efforts to improve the nursing care performance.

\section{ACKNOWLEDGEMENT}

We would like to thank the Director of the Tabanan General Hospital who has provided permission and all nurses who participated in this study.

\section{REFERENCES}

1. World Health Organization. Quality of care: A process for making strategic choices in health system. Geneva; 2006.

2. Amelia R, Hamsah H, Betan AB. Persepsi pasien rawat inap terhadap mutu pelayanan Rumah Sakit Umum Daerah Dara Kabupaten Polewali Mandar [Perception of inpatients towards the services quality of Dara Hospital, Polewali Mandar District]. Journal of Islamic Nursing. 2016;1:20-7.

3. Anjaryani WD. Kepuasan pasien rawat inap terhadap pelayanan perawat di RSUD Tuguredjo Semarang (tesis) [Satisfaction of inpatients towards the nursing care in Tuguredjo Hospital, Semarang (thesis)]. Semarang: Universitas Diponegoro Semarang; 2009.

4. Bogar MM, Nursalam, Dewi Y. Model peningkatan kinerja perawat Unit Gawat Darurat (UGD) berdasarkan asosiasi karakteristik individu, karakteristik organisasi dan karakteristik pekerjaan [Model of Emergency Department nurse performance improvement based on association of individual, organization and job characteristics]. Jurnal Ners. 2013;8(2):271-82.

5. Nikpeyma N, Saeedi ZA, Azargashb E, Majd HA. Problems of Clinical Nurse Performance Appraisal System: A qualitative study. Asian Nursing Research. 2014;8(1):15-22.

6. Nursalam. Manajemen keperawatan: Aplikasi dalam praktik keperawatan profesional [Nursing care management: Application in a professional nursing practice]. In: Aklia Suslia, editor. 4th ed. Jakarta: Salemba Medika; 2014. p. 83-129.

7. Mardiono S, Primitasari A. Faktor-faktor yang mempengaruhi kinerja perawat dalam pelayanan keperawatan di Rumah Sakit Muhammadiyah Palembang tahun 2015 [Factors that influence nurse performance in nursing care at the Muhammadiyah Hospital Palembang year 2015]. Jurnal Kesehatan Bina Husada. 2016;11(4):1-5.

8. Kumanjas FW, Herman W, Jeavery B. Hubungan karakteristik individu dengan kinerja perawat di ruang rawat inap penyakit dalam RSUD Datoe Binangkang Kabupaten Bolaang Mongondow [The association between individual characteristics and nurse performance in the internal medicine inpatient ward, Datoe Binangkang Hospital, Bolaang Mongondow District]. Jurnal Keperawatan. 2014;2(2):1-8.
9. Sabarulin, Darwansyah, Abdullah R. Faktor yang mempengaruhi kinerja perawat dalam medokumentasikan asuhan keperawatan di Rumah Sakit Woodward Palu [Factors that influence nurse performance in documenting nursing care in Woodward Hospital Palu]. Administrasi dan Kebijakan Kesehatan Indonesia. 2013;2(3):29-34.

10. Ridho M, Alimin M, Nurdin P. Faktor-faktor yang mempengaruhi kinerja perawat pelaksana di Rumah Sakit Bhayangkara Tingkat IV Kendari (tesis) [Factors that influence nurse performance in The IV Bhayangkara Hospital Kendari (thesis)]. Makassar: Universitas Hasanudin Makassar; 2013.

11. Rahayu S, Dewi E. Hubungan antara sistem reward dengan kinerja perawat dalam melaksanakan asuhan keperawatan di RSUD Sragen [The association between reward system and nurse performance in the nursing care in Sragen Hospital]. Berita Ilmu Keperawatan. 2009;2(2):51-9.

12. Rutami, Setiawan. Pelaksanaan proses pengkajian keperawatan di ruang rawat inap RSUP $\mathrm{H}$. Adam Malik Medan [The implementation of nursing care evaluation in the inpatient wards of H. Adam Malik Hospital Medan]. Jurnal Keperawatan Holistik. 2012;1(1):52-7.

13. Kambey FVT, Umboh JML, Rattu AJM. Faktor-faktor yang berhubungan dengan kinerja perawat di Rumah Sakit Pancaran Kasih Manado tahun 2016 [Factors associated with the performance of nurses in Pancaran Kasih Hospital Manado year 2016]. Community Health. 2016;1(2):112-28.

14. Ratanto. Pengembangan karir sebagai faktor paling mempengaruhi kinerja perawat pelaksana [Carrer development as a dominant factor that influences nurses performance]. Jurnal Husada Mahakam. 2013;3(5):253-62.

15. Setiawati D. Determinan kinerja perawat di ruang rawat inap Rumah Sakit TNI AL Dr. Mintohardjo (tesis) [Determinants of nurses performance in the inpatient wards of Dr. Mintohardjo Navy Hospital (thesis)]. Jakarta: Univesitas Indonesia; 2010.

16. Mathis RL, Jackson JH. Human resource management. 12th ed. USA: Thomson South Western; 2008. 72-92 p.

17. Hayes LJ, Brien-pallas LO, Duffield C, Shamian J, Buchan J, Hughes F, et al. Nurse turnover: A literature review an update. International Journal of Nursing Studies. 2006;43(2):237-63.

18. Madagi FM, Umboh JML, Rattu JAM. Analisis faktorfaktor yang berhubungan dengan kinerja perawat dalam menerapkan asuhan keperawatan di Rumah Sakit Umum Bethesda Gmim Tomohon [Analysis of factors that associated with nurses performance in implementing nursing care in Bethesda Gmim Tomohon Hospital]. Jurnal e-Biomedik. 2015;3(3).

19. Maulani D. Hubungan pendidikan, motivasi kerja, supervisi kepala ruangan dengan kinerja perawat RSUD $\mathrm{H}$. Hanafie Muara Bungu [The association between education, work motivation and supervision of ward chief with nurses performance in H. Hanafie Muara Bungu Hospital]. Jurnal Wacana Kesehatan Akper Dharma Wacana. 2015;1(2):1-8.

20. Brunero S, Stein J. The effectiveness of clinical supervision in nursing: an evidenced based literature review. Australian Journal of Advanced Nursing. 2008;25(3).

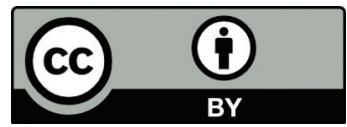

This work is licensed under a Creative Commons Attribution 